\title{
COUNSELLING AND ETHICAL THEORIES
}

\author{
Author(s) / Auteur(s) : \\ Edmundo BALSEMÃO-PIRES \\ Professor \\ University of Coimbra - Portugal \\ edbalsemao@icloud.com
}

\begin{abstract}
Résumé :
The multiplication of counseling interventions, therapeutic models, advisory practices, couching expertise or "think tanks" is a characteristic of the increasing social awareness to the need for control or to the observation of learning in psychological and social contexts. Such trends put under a special focus the contribution of Science and Technology to the best design of the self-observation of organizations. Appropriate answers to specific ethical issues resulting from conflict or stress in the interpenetration of psychic (actions, perceptions and beliefs) and communicative schemes (decision-making sequences, interactional patterns and communicative themes) are also today's concerns.

In my paper, I propose a redefinition of second-order Ethics (after Heinz von Foerster's Second-Order Cybernetics). Second-order Ethics proves to be a valid answer to the needs for an ethical theory able to address the theme of responsibility in personal processes where learning to learn is crucial and also a good tool to face concrete situations requiring therapeutic intervention or counselling in learning organisations.
\end{abstract}

\section{Keywords / Mots-clés :}

ethics; counseling; moral discourse; commendations; second-order cybernetics; observer; objectivity; selfreference; learning

\section{COUNSELLING AND LEARNING}

The concept of counselling as a steering practice partly owes its public success to the contemporary evolution of the parallel notion of therapy. Counselling denotes a miscellaneous steering practice in the methodological approaches, the fields of application and the addresses (individuals and organisations).

Recently, the "Canadian Counselling and Psychotherapy Association" has agreed in the definition of counselling as "a relational process based upon the ethical use of specific professional competencies to facilitate human change. Counselling addresses wellness, relationships, personal growth, career development, mental health, and psychological illness or distress. The counselling process is characterised by the application of recognized cognitive, affective, expressive, somatic, spiritual, developmental, behavioural, learning and systemic principles" (https://www.ccpa-accp.ca/profession/ - accessed September 2018).

An especial field of counselling intervention is the formal organisation, where change and learning are major challenges.

What defines an organization is a community provided with the capacity to process decisions regarding its own outputs, the faculty to submit its members to decisions with disciplinary consequences and the control over its own change.

Inside organizations one finds many levels of interwoven interactions. But the organization is not reducible to a sum of interactions. Management deals with the coordination of interaction, the normative structure and the purposes of the organization in inner and outer changing environments.

As a thick concept, power is used in order to express such coordination. I prefer steering.

The major management's challenge is change. It is change that puts stress in the organization and demands learning and steering competences. 
There are many sources of change. Some are external, others are caused by the organization's normative adaptation to variation in internal communication.

The answers to variation that keep the identity of the organization are surrounded by uncertain conditions. In a changing world the organization cannot take for granted the conservation of its identity. The perception of this risk is reflected in its own structure and in steering plans.

After Chris Argyris's and Peter Senge's works, in the 1990s and along the last two decades "Organisational Learning" is a common title for science and scientific divulgation literature about organisational change and its challenges in a globalised and post-industrial world.

A common and repeated conviction states that modernised organisations demand for the new jobs' skills appropriate to a continuous conversion of labour in knowledge and learning.

Under the concept of collective learning, the contemporary literature in the field has connected systemic thinking, counselling and management and sociology of action.

Regarding the theoretical challenges and for my purposes, I'll identify four basic ideas from the recent literature and I'll describe my own contribution.

From the recent literature -

- Structure influences behaviour - the system causes its own behaviour (Senge, 1990: p. 33). Special attention is needed in the characterisation of learning levels from normative diagrams of the organisation's official strategies (macro-level), to groups (middle-level) and individual members (micro-level).

- Systemic thinking is contrary to reductionism in the investigation of resistances to change in organisations, in groups and in individual behaviour. Counselling strategies should adopt systemic views.

- Systemic thinking applied to management and counselling is aware of the complexity of the perception of change and committed to detect complex relations with appropriate models in tackling learning disabilities in organisations.

- Learning competences are connected to knowledge acquisition and knowledge transfers in groups and organisations. In organisations, globalisation on one hand and the introduction of algorithms based on Artificial Intelligence associated to routines of management of information systems increasingly demand "learning to learn" skills and a quick adaptation.

My contribution will be focused on a special theme not addressed in the literature - normative learning.

Learning in organisations is an emerging product of a variety of factors such as collective strategic anticipation of change, generation of individual motivations to anticipate change and steering actions in favour of adaptation to changing collective goals.

Shoshana Zuboff, quoted by Michael Marquardt, characterised learning as the new form of labour (Marquardt, 2002: p. xiii).

Today, knowledge emergence, knowledge transfers and learning to learn skills inside the organisations are seen as important corporate assets.

Both aspects are not abstracted from normative orientations to action. Transfer of knowledge inside the organisation is sometimes referred as a precondition of learning. However, transference of knowledge is also embedded in normative orientations to communication. In organisations, the cognitive aspects of learning cannot be isolated from normative orientations. Knowledge acquisition and transfer by themselves do not coincide with organisation learning. On the other hand, "communities of practice" don't exhaust the varieties of organisation learning.

This justifies our claim about the relevance of the descriptions of rules' variation with respect to motivation and understanding of duties. In its proper meaning learning is not a simple cognitive disposition towards alternatives of action but entails a normative understanding of the values of the alternatives regarding the system of reference. The alignment of knowledge and behaviour is the ideal 
of learning. But learning is always a process not a final state of coincidence. Thus, an "organisation that learns" is more likely to be the ideal of counselling in the organisation than a real state of things.

The interplay between variation and conservation of structure is reflected in the concept of learning. In psychic systems, organisations or social systems, learning is acquisition and extinction of alternative paths though keeping the same structure. In the learning process as a temporal succession a system doesn't previously know if it survives as the same identical machine after acquiring some alternative sequences.

As acquisition of alternatives, instead of a memorized performance, learning represents always risks for the identity or for the perceived self-identification of the system.

The instability of the learning processes can't be avoided if the system has to confront the challenges of change. The importance of the perception of change for the continuity of organisations is reflected in diagrams of the decision-making and in programs. The increase of the relevance of conditional programming comparing to teleological programming is a symptom of the awareness of the modern organisations regarding uncertainty and the need of learning.

In organisations, the pressure for change and for learning is a variable dependent on internal conditions for variation in the communication and understanding of decisions and of external aspects related to the perceived velocity of the change in the themes of communication relevant for the organisation.

Learning as a process comprehends both levels. This duality of learning can be represented by two channels for the observation and communication of change.

A first channel that links the organisation to the observation of the change of themes in its environment and a second channel that selects and communicates the alternatives to be implemented through decision-making and internal programming. Both channels deal with the sensitivity to velocity and pressure and with the resilience of the organisation in self-identification.

Stress is a concept able to describe these interconnected self-observation mechanisms (see for a general concept of stress in organisations: Koninckx \& Teneau, 2010: p. 26). The evolution of mechanisms to deal with stress reveals the acquisition of learning to learn aptness.

The organisation learns through the adaptation of diagrammatic sequences of the decision-making structure and through the redesign of the normative expectations. Both are consequences of the resonance of change in its normative structure.

At a second-order level of the processing of communication about change the organisation acquires the capacity to form special habits to anticipate the impact of change. These habits form the equivalent to interpretants of learning that keep the organisation prepared to change due to learning to learn skills. Some authors called this adaptation. But adaptation may mean only a first order reaction to variation and not the acquired pre-emptive skills to deal with an acquired need for learning.

The increase of the velocity of change can be a factor in the acquisition of learning to learn habits. But the organisation's internal channel is the critical factor for the stabilization of the interpretants of learning or learning to learn guaranties. There is also a qualitative difference between rules to prescribe behaviour, to implement adaptation to learning and to create learning to learn habits.

People processing is a basic aspect of the organisation's structure of decision-making. In people processing there are many combinations of expectations with diagrammatic-normative (regulationsregulations), diagrammatic-interactional (regulations-behaviour) and personal interaction (people-topeople) dimensions. In organisations, due to the character of restricted groups, "people processing" mobilizes the addresser-addressee form.

The form addresser-addressee supports the processing of information from communicative sequences to psychic systems and inversely. In other writings, I have been arguing that through the addresseraddressee form a co-semiosis of psychic and social systems takes place which doesn't entail the loss of the operative autonomy of the psychic and communicative autopoiesis. This is especially important for the understanding of the distinction between the bio-psychic person, the person as member of the organisation and the officer. 
The allocation of power in the organisations and the use of hierarchic positions to facilitate the transference of selections of possibilities of action from a point to another (N. Luhmann) deal with motivational elements that are situated in a zone of interference of psychic and communicative elements. In organisations, motivation towards objectives is not an organic-psychic predicate of the system of personality but is rooted in expectations connected to the distribution of power. However, motivations situated in the communication of power expectations are read by the organic-psychic personality of the organisations' members: motivation has also the psychic-organic counterpart.

Even if one knows that what is legitimately expected in the organisations is a construction of the distribution of power expectations of the organisation there are interpretations made by the organicpsychic personality that may blur both motivational sides.

The evolution of the theories of therapy and its deadlocks show the importance of the location of the limits between the communicative construction of personality and the psychological personality. In organisations, the influence through power puts in work motivational directions. From the organisation's side the motivational directions respond to communicative needs formulated in internal rules. They represent the organisation's demands that shall be assumed as components of the personae of its members. But the modern organisation's personae don't impose a moral conversion to the members. Coercive implementation of the desired motivational directions is ruled through an amoral discipline. The amorality of the rules of modern organisations means that what is expected from the members doesn't affect the core of the psychological personality. A psychic freedom is open to psychological variation, even though the psychic system is put under stress due to the organisation's motivational trespass.

Therapy or counselling may be needed for a proper interpretation of the double structure of the psycho-social persona.

Here, the central issue is stress caused by motivational trespasses in normative learning processes. A therapeutic approach to stress needs to address the problem of the blurring of the psychological and the social dimensions in motivation and expectations and the behavioural paradoxes and deadlocks that come across.

The correct understanding and definition of motivation in organisations is important both from the perspective of the manager and the member. From self-descriptions of motives emerge cognitive and emotional responses to the organisational demands that may be or may be not adequate from the point of view of the organisation's control or from the perspective of the individual mental health.

Among the interpretations that surface from stress and the blurring of the psycho-social line of the motivational structure are many moral self-diagnoses.

The use of moral grammar is not unusual in the interpretations of the motivational trespasses: just/unjust treatment; respect/violation of ethical codes.

The use of moral vocabulary doesn't mean that we are facing moral dilemmas in the organisation's decision-making processes. This means that the double structure of motivation was captured by the moral language. 


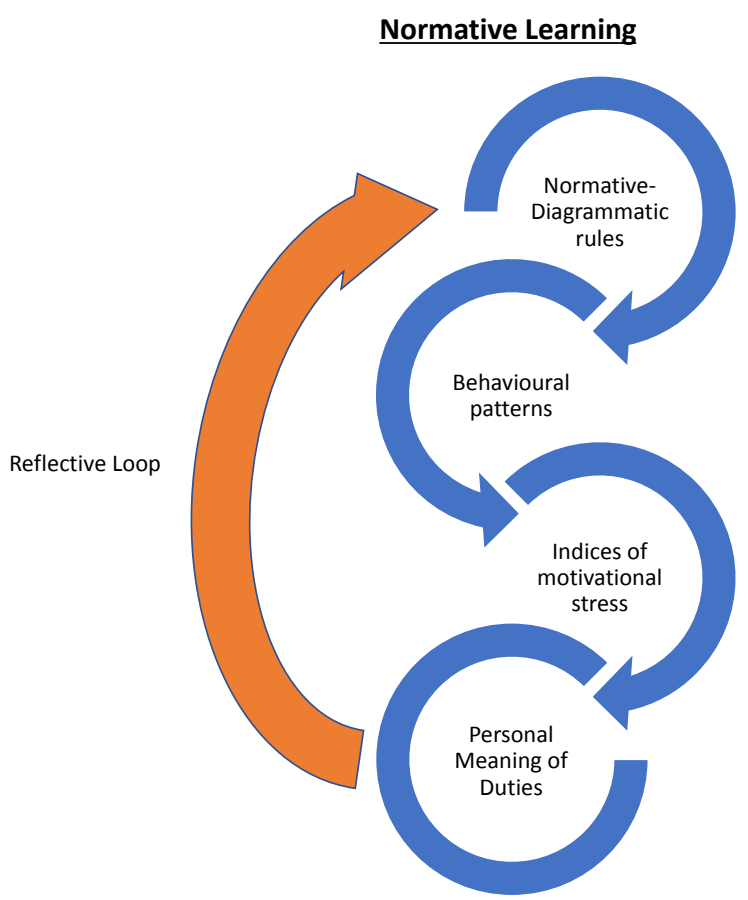

Figure 1 - structural setting of normative learning

\section{FIRST-ORDER ETHICS}

In recent work on meta-Ethics (Richard Hare, Bernard Williams, Martha Nussbaum) the authors identify five main types of ethical theories. The categories go from the "situation ethics", passing through the "ethics of virtue", "moral caring" theories, "right based" theories to "critical thinking".

These theories failed the appropriate relation of the moral categories of responsibility and freedom to the needs of the therapeutic interventions in organisations or interaction characterized by motivational paradoxes or blockages. This was due to their deficient account of the social evolution in the articulation of the epistemic and the practical aspects of the agency or to the ignorance of the role of the double face of motivation with consequences in the practical intentionality of agency and in epistemic-practical blockages.

The contemporary meta-Ethical theories didn't transcend the insufficiencies of the classical model of the "whole and the parts" in the understanding of the contemporary ethical demands in personal, interactional or organisational contexts related to motivational blockages.

The main reason for the insufficiencies of the conventional doctrines is the absence of an explanation of the link between ethical reasoning and learning in situations characterized by psycho-social blurring of the motivational structure.

I call "first-order Ethics" those systems of meta-Ethics (classical and modern) that have abstracted from the complexity of the social and the psychological learning of the motivational structure and its paradoxical entanglement in the formation of the practical duties.

According to such meta-Ethical systems nothing deeply paradoxical occurs as a consequence of the motivational double structure, because normativity and the consensus in social systems apparently reproduce the same moral grounds that a healthy moral reasoning supposedly grasps. What society demands from the individual is morally grounded in a consensus or in a moral reasoning that the rational individual is able to produce or reconstruct. 
An important line of psychological theorizing, Talcott Parsons' theory of culture and personality, the Psychology of Moral Development (L. Kohlberg) and the Socio Learning Theory (A. Bandura) defined the ways through which a psychic system evolve along normative stages, react to models or adapts internally to a symbolic environment with normative components. They believe in a homogeneous normative horizon between social roles, social expectations and moral individual motives and duties. They don't realize that social or organisational expectations are not recipes for the construction of the psychological personality as such. These explanations move in the same terrain where the motivational stress and the paradoxical embarrassments take place. They are not accurate explanations for the motivational stress or even learning in complex systems. Many modern and contemporary Meta-Ethics and psychological theories of motivation and learning evolved from the same belief in an ideal of a motivational structure free from paradoxes due to the motive's double structure and the double source of complexity.

Recently, in the context of the studies of organisational resilience (Koninckx \& Teneau , 2010: pp. 3739 and p. 46) the themes of personal identity, identity crisis, and motivation in organisational contexts were addressed, coping with the same difficulties described above and demanding a systemic approach to adaptive behaviour.

\begin{tabular}{|c|c|c|c|c|c|c|c|}
\hline & $\begin{array}{l}\text { Pre-critical- } \\
\text { Ethics }\end{array}$ & $\begin{array}{l}\text { Situation } \\
\text { Ethics }\end{array}$ & $\begin{array}{l}\text { Ethics of } \\
\text { Virtue }\end{array}$ & $\begin{array}{l}\text { Ethics of } \\
\text { Care }\end{array}$ & $\begin{array}{l}\text { Right- } \\
\text { based } \\
\text { Ethics }\end{array}$ & $\begin{array}{l}\text { Critical } \\
\text { Thinking }\end{array}$ & $\begin{array}{l}\text { Second- } \\
\text { Order } \\
\text { Ethics }\end{array}$ \\
\hline $\begin{array}{l}\text { Ontological } \\
\text { premisses }\end{array}$ & $\begin{array}{l}\text { Metaphysics of } \\
\text { Substance - } \\
\text { parts /whole } \\
\text { relations }\end{array}$ & $\begin{array}{l}\text { Men and } \\
\text { their } \\
\text { situations }\end{array}$ & $\begin{array}{l}\text { Inner } \\
\text { Character }\end{array}$ & $\begin{array}{l}\text { The Self, the } \\
\text { others and the } \\
\text { environment }\end{array}$ & $\begin{array}{l}\text { The Self and } \\
\text { its } \\
\text { entitlements }\end{array}$ & $\begin{array}{l}\text { Society as } \\
\text { environment }\end{array}$ & $\begin{array}{l}\text { Reality is } \\
\text { observer } \\
\text { dependent }\end{array}$ \\
\hline Subject & Human Soul & $\begin{array}{l}\text { Human } \\
\text { Being }\end{array}$ & $\begin{array}{l}\text { Psychologic } \\
\text { al Self }\end{array}$ & $\begin{array}{l}\text { Human } \\
\text { Being in the } \\
\text { world }\end{array}$ & $\begin{array}{l}\text { Individual } \\
\text { Self }\end{array}$ & $\begin{array}{l}\text { Social } \\
\text { situated Self }\end{array}$ & $\begin{array}{l}\text { Persona as } \\
\text { manifold } \\
\text { construct }\end{array}$ \\
\hline $\begin{array}{l}\text { Cognitive } \\
\text { attitudes }\end{array}$ & $\begin{array}{l}\text { Metaphysical } \\
\text { descriptions }\end{array}$ & $\begin{array}{l}\text { First-Order } \\
\text { Descriptions }\end{array}$ & $\begin{array}{l}\text { First-Order } \\
\text { Descriptions }\end{array}$ & Reflective & Reflective & Argumentative & $\begin{array}{l}\text { Second- } \\
\text { Order } \\
\text { descriptions }\end{array}$ \\
\hline $\begin{array}{l}\text { Duties- } \\
\text { Motives } \\
\text { connection }\end{array}$ & $\begin{array}{l}\text { Simple } \\
\text { determination }\end{array}$ & $\begin{array}{l}\text { Context } \\
\text { dependent }\end{array}$ & Prudential rules & $\begin{array}{l}\text { Caring as } \\
\text { existential } \\
\text { connection }\end{array}$ & $\begin{array}{l}\text { Duties are } \\
\text { Rights } \\
\text { reciprocal }\end{array}$ & $\begin{array}{l}\text { Social context- } \\
\text { >psychological } \\
\text { decisions }\end{array}$ & $\begin{array}{l}\text { Non- } \\
\text { determinism/mul } \\
\text { tiple mediations }\end{array}$ \\
\hline $\begin{array}{l}\text { Actions' } \\
\text { sequences } \\
\text { representation }\end{array}$ & $\begin{array}{l}\text { Analogical } \\
\text { Symbols }\end{array}$ & $\begin{array}{l}\text { Analogical } \\
\text { Symbols }\end{array}$ & $\begin{array}{l}\text { Analogical } \\
\text { Symbols }\end{array}$ & $\begin{array}{l}\text { Analogical } \\
\text { Symbols }\end{array}$ & $\begin{array}{l}\text { Recognition } \\
\text { of digital } \\
\text { codes }\end{array}$ & $\begin{array}{l}\text { Recognition } \\
\text { of digital } \\
\text { codes }\end{array}$ & $\begin{array}{l}\text { Analogical/Di } \\
\text { gital }\end{array}$ \\
\hline $\begin{array}{l}\text { Normative } \\
\text { Time }\end{array}$ & $\begin{array}{l}\text { Moral } \\
\text { Deliberation }\end{array}$ & $\begin{array}{l}\text { Existential } \\
\text { Time }\end{array}$ & $\begin{array}{l}\text { Moral } \\
\text { Deliberation }\end{array}$ & $\begin{array}{l}\text { Existential } \\
\text { Time }\end{array}$ & $\begin{array}{l}\text { Legal } \\
\text { sequences/D } \\
\text { eliberation }\end{array}$ & $\begin{array}{l}\text { Moral } \\
\text { Deliberation }\end{array}$ & $\begin{array}{l}\text { Parallel } \\
\text { distributed } \\
\text { processes }\end{array}$ \\
\hline $\begin{array}{l}\text { Normative } \\
\text { Learning }\end{array}$ & $\begin{array}{l}\text { parts/whole } \\
\text { integration }\end{array}$ & $\begin{array}{l}\text { Subject's } \\
\text { adaptation }\end{array}$ & $\begin{array}{l}\text { Subject's self } \\
\text { improvement }\end{array}$ & $\begin{array}{l}\text { Changes in } \\
\text { subject's } \\
\text { accountability }\end{array}$ & $\begin{array}{l}\text { Rights } \\
\text { acknowledge } \\
\text { ment }\end{array}$ & $\begin{array}{l}\text { Argumentation } \\
\text { skills }\end{array}$ & $\begin{array}{l}\text { Deutero- } \\
\text { Learning }\end{array}$ \\
\hline
\end{tabular}

Figure 2 - normative learning and metaethical theories 


\section{LEARNING TO LEARN THROUGH SECOND-ORDER ETHICS}

Take the following as an ideal experiment in the context of organisational learning.

- What do you want from me?, asks the organisation's member to the community.

In this question it is not the individual alone that asks. The self is itself suspended in the question. The question itself asks backwards and means: what can I want from what you want from me?

The question formulates an equivalent to the bifacial structure of motivation.

The circularity of a psychological response to a social demand can't erase the fact that what an organisation wants from an individual never coincides with the individual construction from an internal, psychological or moral, point of view. The individual can articulate the social demand with a psychological intention in order to give an answer to the demand. But the social demand and the ensuing configuration of the personal roles don't cause the psychological counterparts of the obligations.

Society or organisations don't shape the motivational orientation of the individual according to a single determination.

Even the contemporary literature consecrated to "social learning" (A. Bandura and others) in its portrayal of vicarious learning from personal models, did not address the conundrum evolving from the miscellaneous construction of the personal obligations and roles.

The syncretic fusion of the psychological and the social personae is a symptom of a pre-modern normativity, which ignores change (time) and self-referential responses to change through expectations. In a functional differentiated society normative learning entails the understanding of duties and rights from a reflective perspective about the source of validity of the norms, which entails complexity, autopoietic autonomy and parallel distributed processes (PDP).

This doesn't mean only that one understands normative content within a biographical, social and organisational frame.

Duties and rights are shaped against the contrasting background of the psychological persona and the social persona. This contrasting background is learned, must be learned, and is constantly evolving.

The psychological self and its social counterparts learn the difference between norms and duties that depend on the power and normative diagrams of the society or organisations which are connected to specific expectations and the duties that arise through interaction or from inner commitments towards oneself. These duties have different meaning, mainly because they are articulated with different levels of the person according to complex, non-linear, associations similar to what occurs in parallel distributed processes.

A pre-reflective, first-order fusion of the personalities and its manifestation in behaviour expresses itself in obstacles in the learning of norms. Such fusion produces paradoxical situations similar to those already portrayed in Gregory Bateson's and Paul Watzlawick's work on pathologies of communication.

Here lies also what I have identified as "motivational stress" in my book Second Order Ethics as Therapy (Balsemão-Pires, 2016: p. 51-53).

Situations characterised by motivational stress emerge in a variety of levels from the psycho-somatic, the behavioural and valuation level noticeable in habits, to the capacities involved in learning to learn and normative learning.

According to my view, motivational stress that paralyses normative learning is a consequence of personal blockages at a first order level of the understanding of duties. These obstacles affect the motivational structure of the social personae at the following dimensions.

- The general understanding of duties; 
- The capacity to adapt to organisational new demands and ethical commitments towards the organisation;

- The capacity to fully recognise the person's "role-set" and corresponding deontological components in an integrated, non-conflicting approach.

- The individual coherence between the person as a psychological and as a social construction.

Counselling needs to adopt a non-fusional or de-fusional normative learning, which entails both second-order observations and learning to learn abilities turned to complex changing environments.

If my model of the structure of motivation is right, from its development the relation between ethics, learning and therapy will become noticeable under another light.

Let me clarify the steps of my reasoning, restating, again, some theses already developed in Second Order Ethics as Therapy.

According to the communicative conditions of the functional differentiated society it is not possible to subordinate the biographical references of the agents under a meta-biographical coherence of the type of the "whole and the parts" model, common to the medieval religious morality, Lorde Shaftesbury's or Christian Wolff's meta-ethical models, encompassing the alleged world's moral order and the individual's virtuous agency.

This means that moral conflicts cannot find their redemption in religion, their solutions in a superior moral order above the singular perspective of the agents or in moral consensus. The modern institutionalization of legal answers to moral conflicts is not a consequence of a moral character of the Law System. Differently, the autopoiesis of the Law System reveals the capacity of the law to offer a detour for the initial moral equations of moral conflicts.

The growth of legal issues and deontological dilemmas inside and around the organisations proves the de-fusionist strategy of the modern organisation's politics regarding what represents the duties of its members.

Outside organisations, an exclusive moral understanding of the coordination in ego-alter interactions offers a fragile ground for stability in complex social environments. The moral concepts that were traditionally related to the classic concepts of honesty and decorum, such as honour or the given one's word, are aspects of the concept of order typical of the "whole and the parts" meta-ethical model and of a pre-modern ruling of interactional patterns.

A major transformation occurred in consequence of the loss of vitality of the view of society as a universe, an objective order independent of the observers. After William James, H. von Foerster's allusion to a multiverse reflects a new orientation to social relations that have no fixed centre or a prearranged order.

Information has become plastic and is no longer directed to fixed cognitive effects. Consequently, each individual has an irreducible responsibility to construct his (her) singular views on what is right/duty in his (her) plans of life. Responsibility in interactions results from the freedom to put the plans of life under the individual's own hands, even if the construction of a plan of life is under constant scrutiny.

According to Heinz von Foerster's own concept, "dialogue" is characterized by a concrete multiverse that stimulates the mutual reflection of the persons and the coreference of mutual responsible acts. "Dialogue" constitutes a living reflective practice of second-order observations, dislodging fixed beliefs or making possible this result through the exchange of the "taking the role of the other" between ego and alter. Due to its capacity to correlate the basal self-reference of a person through the responses of the other, dialogue is the medium that can operate as a second-order modal reconfiguration of the beliefs and practical commitments of the agents. But in the dialogic constitution of a responsibility for the plans of life one can identify also the biographical horizon of the Ethics of responsibility and a structure for the processing of learning. Of course, one knows that the notions of a dia-logic and dialogue can be misleading. With the use of this term H. von Foerster was not referring to logos or reason, but essentially to the practice of responding. I prefer this idea of a responsive praxis 
to the word dialogue, because responsiveness expresses responsibility and mutual coordination of expectations through acts mobilizing the "taking the role of the other" attitude.

I'll propose to reconstruct the concept of a moral self in the notion of an observer of morality involved in the practice of responding. Any observer is limited and temporally constrained. The moral observer is someone limited but also interested in a course of actions with others. The bounded moral self is inferred from the concrete praxis of responding to others in interactions. Moral interest explains the inner involvement of the observer in the courses of actions as a consequence of its bounds. The possibility of involvement in actions modifies the observer in an agent and inversely. The variety of ways of the involvement of the observer also defines the multiplicity of the moral explanations for its actions or motives and the value given to the "taking the role of the other" in responsibility.

The seminal literature on "situated learning" and "communities of practice" (Lave, 1985; Lave \& Wenger, 1991) emphasised the value of the concrete interactional web of relations in people colearning in community contexts. These are exemplified by groups of people, official or not, achieving the common goal of sharing knowledge and skills on a domain or subject. The ideas on collective learning in practice points to cooperative practices where the taking the role of the other, conversation or dialogue are pivotal. They have in common with the models of organisational learning the goals of knowledge improvement and knowledge transfers.

I agree that these aspects of learning in practice are essential, but the complete model of the organisational learning to learn should include normative learning and needs clarification on the subject of the scope of counselling in the implementation of the communities of practice.

Counselling as an auxiliary steering activity in organisations can succeed in diagramming the organisation's needs regarding communities of practice that are not emerging spontaneously and at the same time can determine where are the needs for psychotherapy.

Second order Ethics is a consequence of second-order observations in the context of the interactional responsive praxis, inside or outside organisations, that should be supposed in counselling.

A second-order observation is a typical product of the correlation of reflection and time in the acquisition of self-reference. Briefly, second-order observation is observation of observers in their operations, according to H. von Foerster's definition. The full admission of the concept of a secondorder observation implies the thesis of a first-order observation and the relation between observers of the first- and second-orders. The relation between both observations has analytic and descriptive importance for the definition of descriptions of facts, actions and norms. As observation of observers the second-order observation produces the suspension of the mental attitudes towards the objects in the world of first-order observers or naïve interpreters. Through second-order observations the information available to the first-order observers is put back in a situation of cognitive indeterminacy and openness to other possibilities. It follows that a second-order observer can perceive the limitations of the first-order observer. The cognitive content of the first-order observer can then be placed within the frames of specified mental attitudes or cognitive and practical schemes. This framing of the self has effects similar to those of Edmund Husserl's phenomenological "epoché" regarding the "natural attitude" of the naïve observer. Such transformation of the naïve attitude makes visible the particular selections of the available information of the first-order observer.

In the field of therapy and counselling, second-order observations emerge whenever an individual opens its views assuming the role of the other and the possibilities open to action from the other's horizon. It is similar to the cognitive processes at stake in collective situated learning in communities of practice.

The taking the role of the other is not equivalent to passive imitation of a model or identification in vicarious learning, as diagnosed in the explanations of the social learning theorists.

In conversation the individual understands that what defines its action's selections is never the same as the alter's selections. The self is not forced to undertake a transformation of the inner life to be able to cope with the alter's, the organisation's or society's demands. Alter's selections or the normative 
diagrams of the organisation are real possibilities but not possibilities of the inner life of the ego. Thus, dialoging in practice ego learns how to adapt to norms and especially to normative change.

This second-order consequence represents learning as understanding of alternative selections and motivational paths. Many blockages can be dissolved through second-order techniques.

Second-order therapy puts the motives against the background of the possibilities open to action, through a stimulation of learning in responsive situations. Additionally, second-order therapy enlightens the distinction of motivation of the inner life and motivation related to social expectations. Its central aim is learning to learn, that means to instruct oneself on how to discover possibilities where a former experience fixed only facts or crystallized paths.

Only from a second-order outlook one can perceive the conflicts or biases regarding values/aims of individual's or group's conduct as consequences of communicative/epistemic blockages at a firstorder level.

These difficulties were scrutinised in the case of the "double bind" cognitive phenomena in the work of G. Bateson, P. Watzlawick, J. B. Bavelas and D. D. Jackson, the Palo Alto team, in individuals and organisations. Semantic difficulties related to what G. Bateson identified under the distinction of map/territory or first- and second-order processes can be considered under the distinction of first- and second-order meanings. Even perceptual problems arising from the blurring of the distinction of frame/picture can be depicted with the distinction of first- and second-order formation of images. Blockages regarding values/aims can be seen as consequences of the agent's incapacity to formulate a second-order observation regarding the conflict. Many "cultural" conflicts are of this sort.

The efficacy of a second-order therapy in a personal, interpersonal or organisational context depends on the ability to induce recursive behaviour.

Recursive behaviour is a cognitive/normative construction and means the inducement of actions that can be perceived by the agent as contributing for the recovery from a situation of conflict due to its own communicative/epistemic biases or blockages. Here, one can see the formation of duties toward oneself and toward the others as outcomes of second-order observations or meta-communication. Regarding the motivational dimension the recursion through second-order therapy points to the defusing of the motive's blended structure.

These duties are like therapeutic rules acquired in the practice of learning through the appropriate conversational habits.

\section{RÉFÉRENCES}

BALSEMÃO-PIRES, Edmundo (2016) Second Order Ethics as Therapy, Saarbrücken: LAP.

BANDURA, Albert (1971) "Social Learning Theory" in General Learning Co., New York, General Learning Press, 1971.

BANDURA, Albert (1999) "Social Cognitive Theory. An Agentic Perspective" in Asian Journal of Social Psychology (1999) 2, pp. 21-41.

BATESON, Gregory (1972) Steps to an Ecology of Mind, Chicago: University of Chicago Press.

BEAUREGARD, Nancy, Louise LEMYRE, and Jacques BARRETTE (2015) "The Domains of Organizational Learning Practices: An Agency-Structure Perspective” in Societies 5, pp. 713-733.

FOERSTER, Heinz von (1991) Éthique et Cybernétique de Second Ordre. In Y. Ray \& B. Prieur (eds.), Systèmes, Éthique, Perspectives en Thérapie Familiale, Paris: ESF éditeur, pp. 41-55.

GLASERSFELD, Ernst von (1983) "Learning as Constructive Activity" in Bergeron, J. C. \& Herscovics, N. (eds.) Proceedings of the 5th Annual Meeting of the North American Group of Psychology in Mathematics Education, vol 1 Montreal: PME-NA.

GLASERSFELD, Ernst von (1995) Radical Constructivism: a Way of Knowing and Learning, London, Washington D. C.: The Falmer Press.

HARE, Richard (1952) The Language of Morals. Oxford: Oxford University Press. 
HARE, Richard (1999) Objective Prescriptions. Oxford: Oxford University Press.

KONINCKX, Guy \& Gilles TENEAU (2010) Résilience Organisationnelle. Rebondir face aux Turbulences. Bruxelles : Éditions de Boeck Université.

LAVE, Jean (1985) "The Social Organisation of Knowledge and Practice: A Symposium" in Anthropology \& Education Quarterly 16, pp. 171-176.

LAVE, Jean \& Étienne WENGER (1991), Situated Learning. Legitimate Peripheral Participation, Cambridge: Cambridge University Press.

LE NY, Jean-François; Montpellier, Gérard de; Oléron, Geneviève (1968) Traité de Psychologie Expérimentale, IV - Apprentissage et Mémoire, Paris: P. U. F..

LUHMANN, Niklas (1978) "Soziologie der Moral" in N. Luhmann \& S. H. Pfürtner (eds.), Theorietechnik und Moral (pp. 8-116), Frankfurt/M.: Suhrkamp.

LUHMANN, N., SHORR K. E. (Hrsg.), (1982) Zwischen Technologie und Selbstreferenz, Frankfurt/M.: Suhrkamp.

LUHMANN, Niklas (1984) Soziale Systeme, Frankfurt/M.: Suhrkamp.

LUHMANN, Niklas (1993) Gibt es in unserer Gesellschaft noch unverzichtbare Normen? Heidelberg: C. F. Müller Juristischer Verlag.

LUHMANN, Niklas (1997) Die Gesellschaft der Gesellschaft, Frankfurt/M.: Suhrkamp (2 vols.).

MARQUARDT, Michael J. (2002) Building the Learning Organization. Mastering the Five Elements for Corporate Learning, Palo Alto (CA): Davies-Black Publishing, Inc.

MOON, Jennifer A. (2004) A Handbook of Reflective and Experiential Learning, London and New York: Routledge Falmer.

PARSONS, Talcott (1951) The Social System, London: Routledge and Kegan Paul.

PARSONS, Talcott \& SHILS, Edward, (1951) Toward a General Theory of Action, Cambridge (Mass.): Harvard University Press.

PIAGET, Jean (1959) “Apprentissage et Connaissance” in Idem, Études d' Épistémologie Génétique, vol. VII, Paris: P.U.F., pp. 21-67.

SCOTT, Brenda Barker (2011) "Organizational Learning: A Literature Review" in IRC Research Programm, discussion paper \#2011-02, Queen's University: Kingston.

SENGE, Peter M. (1990) The Fifth Discipline. The Art and Practice of the Learning Organization, New York, London, Toronto, Sidney, Auckland: Currency Doubleday.

SHAFTESBURY (2001) "An Inquiry concerning Virtue, or Merit” in Idem, Characteristicks of Men, Manners, Opinions, Times, volume II, Indianapolis: Liberty Fund Inc..

WATZLAWICK, Paul, BAVELAS, J. J., and JACKSON, D. D., (1967) Pragmatics of Human Communication. A Study of Interactional Patterns, Pathologies and Paradoxes, New York, London: W. W. Norton \& Company.

WILLIAMS, Bernard (1993). Ethics and the Limits of Philosophy. London: Harper Collins. 
